\title{
DEMOGRAPHIC DEVELOPMENTS IN FIER REGION DURING THE TRANSITION PEROID
}

DOI: http://dx.doi.org/10.18509/GBP.2015.30

UDC: $314.116(496.554)$, ,1989/2011“6

\author{
Assoc. Prof. Valbona Duri \\ Phd.Adela Dhromaj \\ "E.Cabej" University, Gjirokaster, Albania.
}

\begin{abstract}
During the transition period, the population in Fier region is characterized by dynamics (by the change and the movement). First of all, this dynamic has been followed by the dynamic of the total economic - social - political processes, and changes in some stages and regional specifications too.

According to statistics, the population of the county after 1990 there was a decrease of about 1.3 times less than before. This situation, has two reasons: the decline of natural increase (reduced by over 3 times), and the impact of migration from the county to the capital city of Albania and to abroad. The greatest impact is because of the reduce of the natural growth has been the decline of the birth rate coefficient from $14.5 \%$ to $10.1 \%$ (2001) and $24.3 \%$ (1989).

The evolution of the population in this county presents differences in spatial terms: according settlements city - village, district and municipalities. The phenomenon that is observed by urban-rural settlements is that the growth of urban population is more than its natural growth and for the village has been the reverse.

The changes identified in the density of the county population. The average population density has fallen to $163 \mathrm{~h} / \mathrm{km}^{2}$ of $202 \mathrm{~h} / \mathrm{km}^{2}$ (1989).

Population in this county is older than 22 years ago. The population over 65 years is $12.1 \%$ from $7.1 \%$ in 2001 , and the reduction of the new age (1-15 years old), is greater than the increase of population over 65 years old.
\end{abstract}

KEY WORDS: Average annual growth, rate of birth, natural growth, mechanical change, migration

\section{INTRODUCTION}

After the year 1990, population in the Fier county underwent a lot of changes which affected its quantitative and qualitative indicators. This article focuses on the analysis and highlighting of changes and tendencies noticed in the quantitative dimension (the general number of population in the county), under the influence of new socio-economic and political circumtances, which affected the Albanian society, at the end of 1980. The Fier county comprises three districts: Fier (the county seat), Lushnje and Mallakaster.

\section{The numerical evolution of the population in the Fier county during the time period under discussion.}

The demographic situation in the region the article talks about after 1989, is without a doubt a result of the geographic, political, economic, social and demographic factors etc. The statistics shows that after 1990, the population in the Fier region shows an increase by 1.3 times against the year 1989 . 
Table Nr.1 The population in the Fier region (resident population), 1989-2011, in \%. [2]

\begin{tabular}{|l|c|c|c|c|c|}
\hline \multirow{2}{*}{ Units } & \multicolumn{4}{|c|}{ Years } & \multicolumn{2}{c|}{2011} \\
\cline { 2 - 6 } & 1989 & \multicolumn{2}{|c|}{2001} & a.a.g. \\
\cline { 2 - 6 } & Nr. of pop. & Nr. of pop. & Nr. of pop. & $\begin{array}{c}{ }^{1} \\
2001-2011\end{array}$ \\
\cline { 2 - 6 } & 381532 & 483269 & 2.0 & 494116 & 0.2 \\
\hline Region & 101600 & 187126 & 5.2 & 202375 & 0.8 \\
\hline Urban area & 279932 & 296143 & 0.5 & 291741 & 0.1 \\
\hline
\end{tabular}

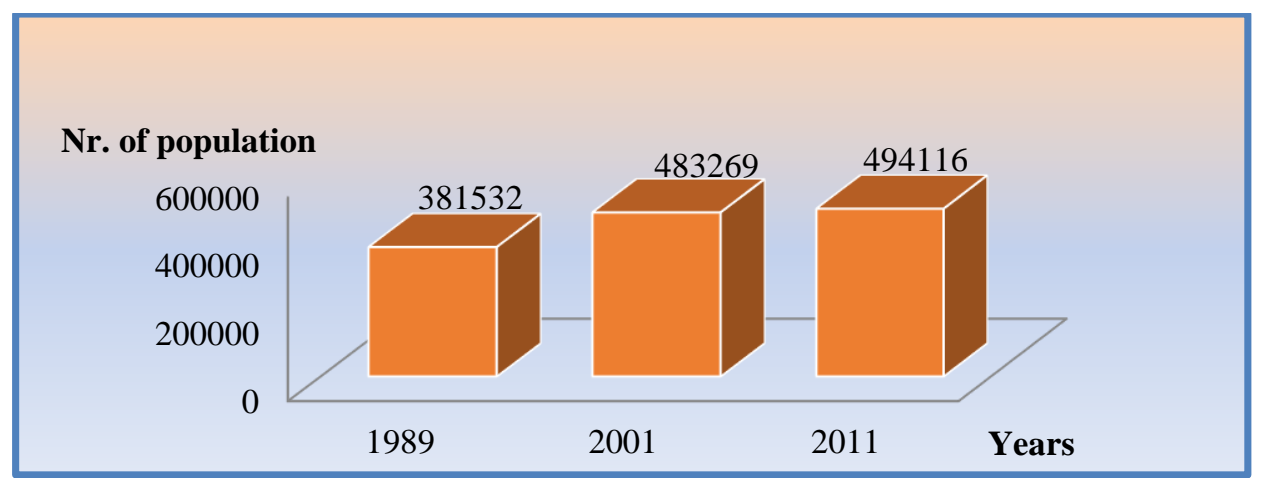

Figure No1. The evolution of the (resident) population in the Fier region (1989-2011) [2]

This growth is lower (by about 1.3 times), compared with the previous time period (19501989), where the population according to the 1989 census was 3 times bigger than in the year 1950.

Such a situation, has resulted in a decrease in the natural growth rate and the internal migration from the county to the capital city and even abroad. To see what influence the decrease in the natural growth rate has had we refer to the statistics in the table below. The natural growth rate coefficient for this population for the year 2011 is below $6.0 \%$ o $(5.8 \%$ ) from $19.5 \%$ in the year 1989 . The calculations show that this indicator during the period of 22 years has been reduced by over 3 times. The great decrease in birth rate coefficient of the county to $10.1 \%$ from $14.5 \%$ (2001) and $24.3 \%$ (1989) has had the biggest influence on the reduction of this indicator.

Table No.2 . The natural growth rate of population in the Fier county (1989- 2011), in \%o. [3 ]

\begin{tabular}{|l|c|c|c|c|c|c|c|c|c|}
\hline \multirow{2}{*}{ Units } & \multicolumn{9}{c|}{ Years } \\
\cline { 2 - 11 } & \multicolumn{3}{|c|}{$\mathbf{1 9 8 9}$} & \multicolumn{3}{c|}{$\mathbf{2 0 0 1}$} & \multicolumn{3}{c|}{$\mathbf{2 0 1 1}$} \\
\cline { 2 - 11 } & N.G. $^{\mathbf{2}}$ & K.F. $^{\mathbf{3}}$ & K.M. $^{\mathbf{4}}$ & N.G & K.F. & K.M. & N.G & K.F. & K.M. \\
\hline County & 19.5 & 24.3 & 4.9 & 10.7 & 14.5 & 3.8 & 5.8 & 10.1 & 4.3 \\
\hline Fier district & 19.0 & 24 & 5 & 10.8 & 14.6 & 3.8 & 4.7 & 11.7 & 4.3 \\
\hline Lushnje district & 20.0 & 24.7 & 4.7 & 9.8 & 13.7 & 3.9 & 3.2 & 7.4 & 4.2 \\
\hline Mallakastër distr. & & - & - & 13.1 & 17 & 3.9 & 6.9 & 11.2 & 4.3 \\
\hline
\end{tabular}

[1] Annual average growth

${ }^{2}$ Natural growth

${ }^{3}$ Fertility Coefficient

${ }^{4}$ Mortality Coefficient 
Table No.3. The mechanical population growth rate of resident population of the Fier region (1989-2011), in \%o [2] Accrued by V. Duri \& A.Dhromaj.

\begin{tabular}{|l|c|c|c|c|c|c|}
\hline \multirow{2}{*}{ Units } & \multicolumn{6}{|c|}{ Years } \\
\cline { 2 - 7 } & \multicolumn{3}{|c|}{$\mathbf{2 0 8 9}$} & \multicolumn{3}{c|}{ 2001 } \\
\cline { 2 - 7 } & M.G $^{\mathbf{5}}$ & K.M. $^{\mathbf{6}}$ & K.E. $^{\mathbf{7}}$ & M.G & K.M. & K.E. \\
\hline Region & 4.3 & 9.2 & 4.9 & -4.0 & 5.7 & 9.7 \\
\hline Fier & 5.7 & 10.0 & 4.3 & 2.2 & 6.1 & 8.3 \\
\hline Lushnje & 1.8 & 7.7 & 5.9 & 3.6 & 5.5 & 9.1 \\
\hline Mallakastër & & - & & -15.1 & 4.5 & 19.6 \\
\hline
\end{tabular}

Statistics for the coefficient of migration balance constitute an important factor in the analysis of population decrease in the county, after 1989.

\section{The evolution of population in Fier region from the spatial point of view}

\section{The evolution of population in Fier region according to the type of settlement (urban - rural).}

The phenomenon which is encountered according to the type of settlement is that the increase in urban population is bigger than the natural growth rate whereas the contrary is true for the village.

While the general population until 2001 has increased by $18.7 \%$ the urban population has increased by $21.4 \%$ compared with 1989 . After this year, during the last two censuses population has decreased also in the urban area of the county by $0.02 \%$ on average per year compared with an increase of $1.6 \%$ in the previous interval (1989-2001).

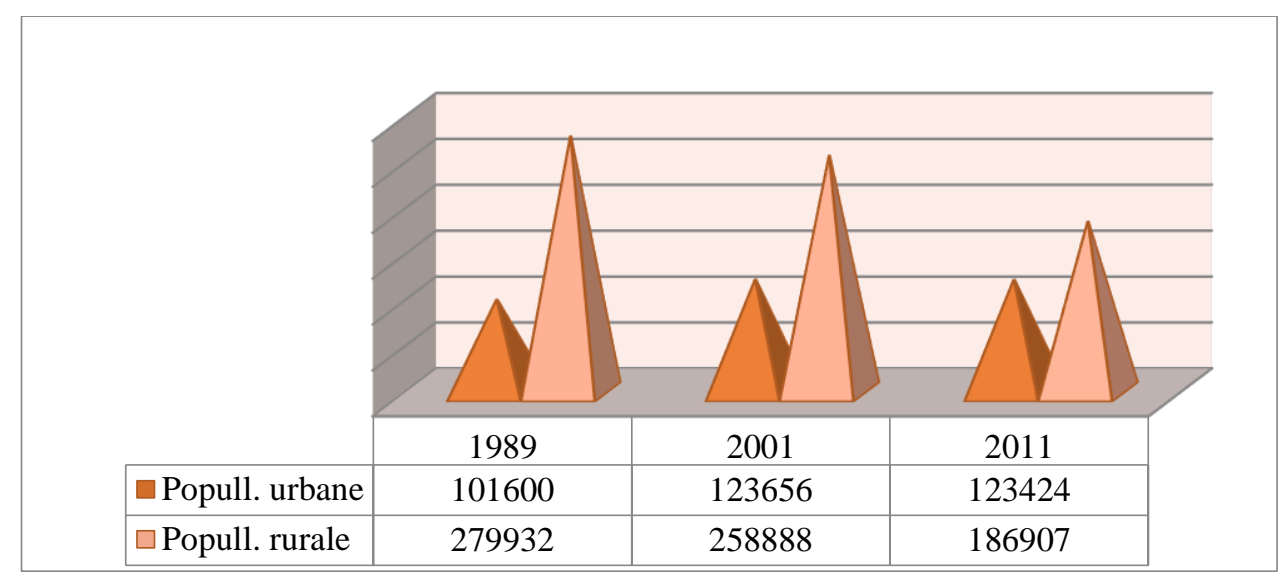

Figure No.2 The population of Fier county according to the districts (1989-2011)[5 ], [1 ], [4 ]

\section{Population in Fier region according to the type of settlement (urban - rural)}

While the rural population has decreased by 33.2\% of its general number (after 22 years), on average by $3.2 \%$ per year (r.m.v. $-3.2 \%$ ), which means that it has migrated more outside the county than towards its urban area (of the county), at a time when the urban population itself has experienced a decrease (2001-2011).

\footnotetext{
${ }^{5}$ Net Migration

${ }^{6}$ Coefficient of immigration

${ }^{7}$ coefficient of migration
} 


\section{The evolution of the population in Fier region according to the districts.}

By analyzing the tendency of the general number of population of the county, according to the districts, we see that only the populations of two districts Fier and Lushnje are characterised by increase. The Mallakastër district exhibits a growing negative net migration rate coefficient.

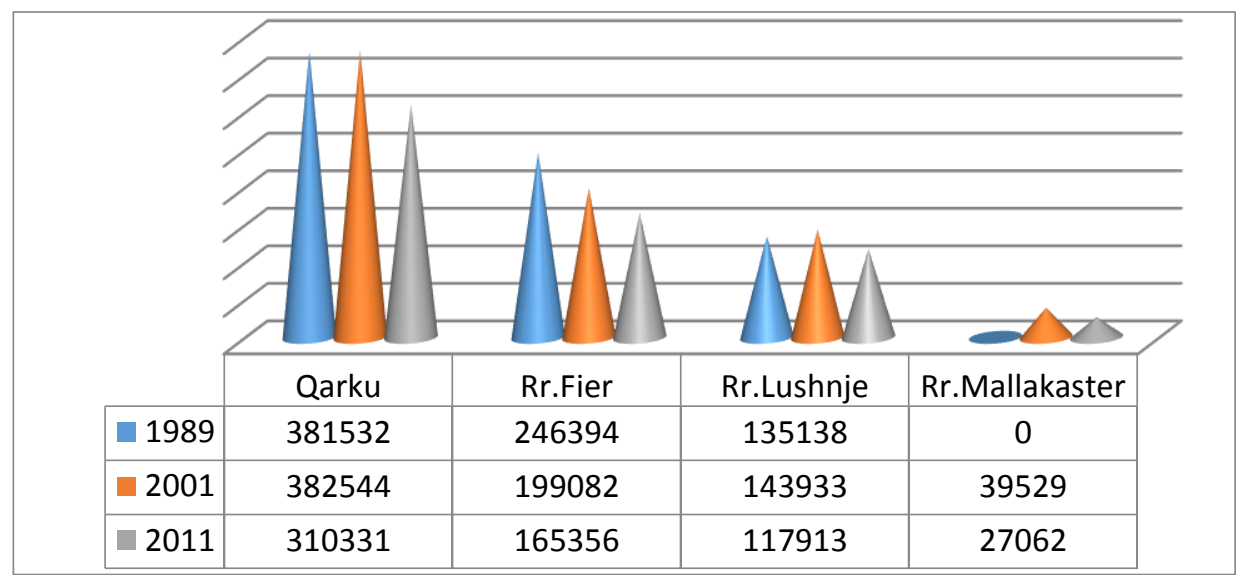

Figure No. 3. The population of Fier according to the districts [1]

\section{According to the communes}

Changes can also be seen according to the communes. Depending on the tendency which the variation in the number of population according to the communes has had, what can be seen from the comparison between the last two censuses is a decrease of population in all the communes but with different intensity. The biggest decrease of population is seen in the communes: Levan (-3390 h.), Cakran (3077 h.) and Qëndër (2523 h.). This category of communes is followed by those where the population decease varies from $1200 \mathrm{~b}-2260 \mathrm{~b}$, where $50.0 \%$ of the communes of the county fall into this category. Whereas the communes with a lower population decrease, which varies from $385 \mathrm{~h}$. 1200 h. constitute only $34.0 \%$. 


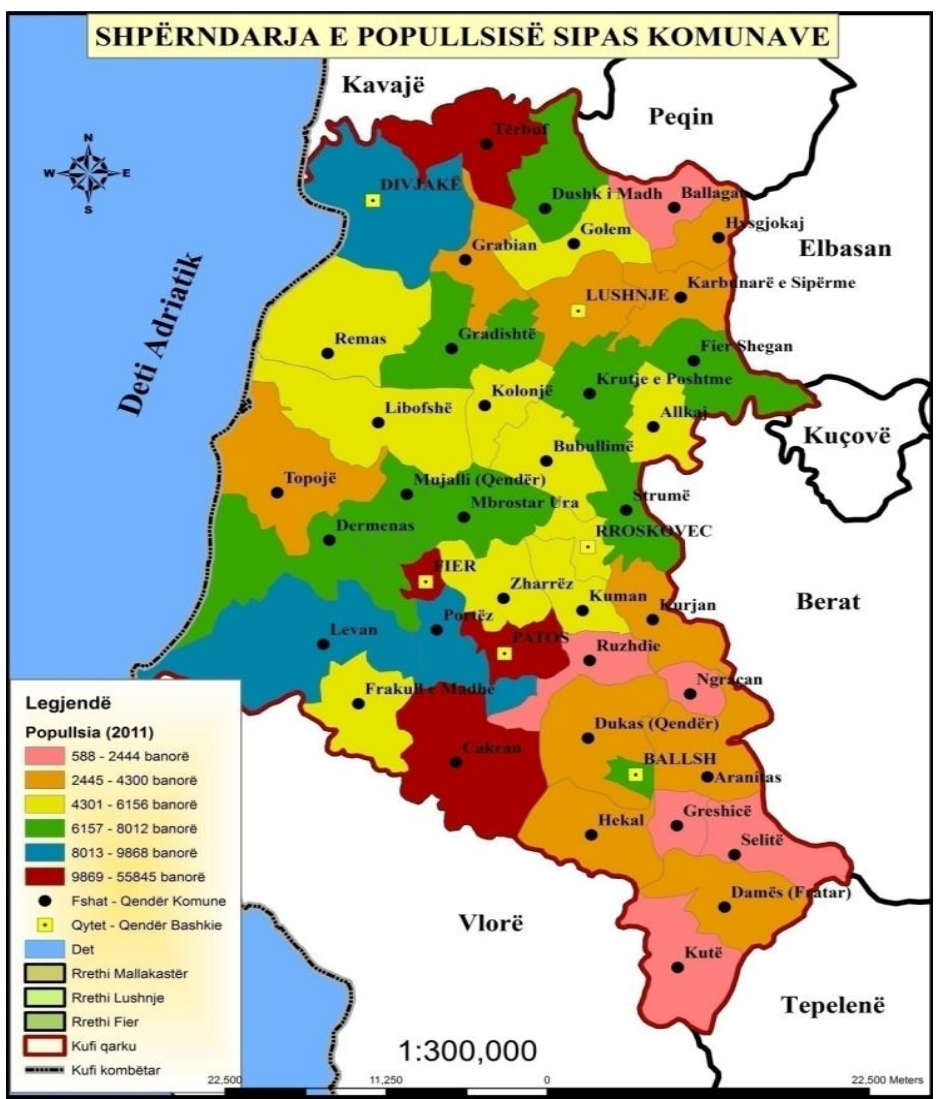

Figure No. 4. The map of population number in Fieri region [4]

Accrued by A.Dhromaj

\section{THE POPULATION DENSITY IN FIERI REGION (1989-2011)}

The manner and population density, are important indicators where the socio-economic development of a country and the demographic policy which is pursued manifest clearly and openly.

Being a long historical process, the territorial distribution of the population is a result of the influence of many factors, such as, geographic, natural, socio-economic, demographic, etc,.

Fier region with an area of 1910 square $\mathrm{km}^{2}$ constitutes about $7.0 \%$ of the entire area of Albania and houses $11.1 \%$ of the population, (2011), with an average population density $162.5 \mathrm{~h} / \mathrm{square} \mathrm{km}^{2}$. Such a situation shows about a high population density in the Fier region, compared with the average of Albania $97.0 \mathrm{~h} / \mathrm{squarekm}^{2}$, which makes it the third most densely populated county in the country.

Table No. 4 The population density of the region by districts, [5] , [1]

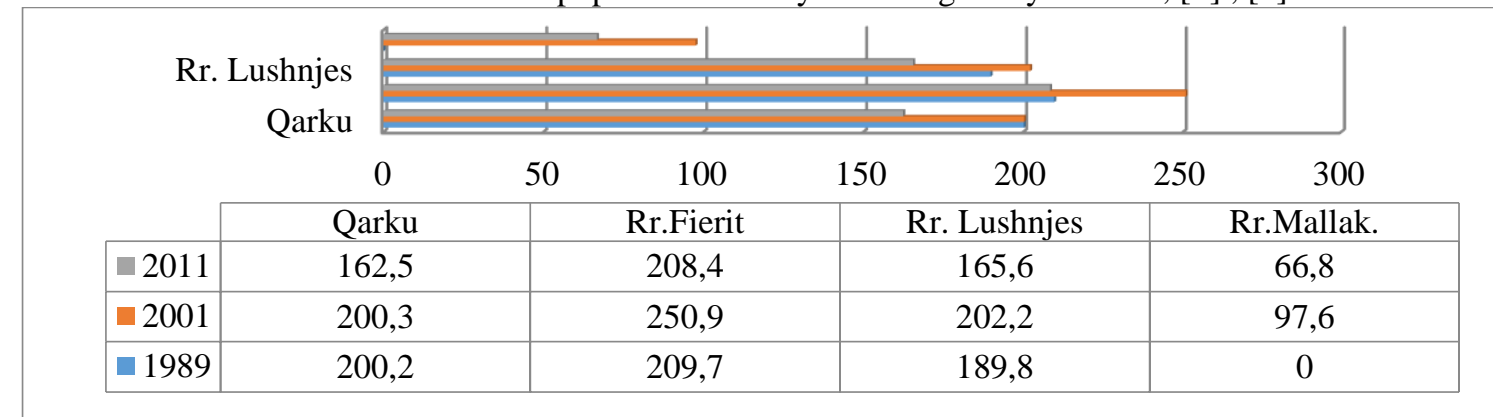


This population is un-uniformly (unequally) distributed, from the spatial point of view according to the cities and villages, districts and communes, etc.

- $60.0 \%$ of the county population is in the village and occupies about $84.4 \%$ of the area of the lacounty, whereas about $40.0 \%$ of the population is in the cities.

Table Nr. 5. The population distribution in Fier region (urban -rural), in (\%). [5],[1]

\begin{tabular}{|l|r|r|r|r|r|r|}
\hline \multirow{3}{*}{ Units } & \multicolumn{3}{|c|}{ Years } \\
\cline { 2 - 7 } & \multicolumn{2}{|c|}{1989} & \multicolumn{2}{c|}{2001} & \multicolumn{2}{c|}{2011} \\
\cline { 2 - 7 } & Surface & Pop. & Surface & Pop. & Surface & \multicolumn{1}{c|}{ Pop. } \\
\hline Region & 100.0 & 100 & 100.0 & 100 & 100.0 & 100 \\
\hline Urban area & 15.6 & 26.6 & 15.6 & 32.3 & 15.6 & 39.8 \\
\hline Rural area & $\mathbf{8 4 . 4}$ & $\mathbf{7 3 . 3}$ & $\mathbf{8 4 . 4}$ & $\mathbf{6 7 . 7}$ & $\mathbf{8 4 . 4}$ & $\mathbf{6 0 . 2}$ \\
\hline
\end{tabular}

After 1990, population tends to concentrate more and more on the cities.

- According to the districts, $62.0 \%$ of the urban population of the county is in the city of Fier, (the biggest administrative centre of the county). Whereas less than (6.2\%), in the district of Mallakastër. This is due to the population migration to Fier, also to Tirana, Durres, but also abroad in search of a better life.

- According to the communes, by refering to the population rate we see differences which are given in the maps below that deal with population density in Fier region. 18 communes which constitute $50.0 \%$ of the total number of communes in the Fier region, have a lower population density than the rural average of the county $\left(114 \mathrm{~h} / \mathrm{square}^{2} \mathrm{~km}^{2}\right.$, at a time when the other half of the communes have a population density above the average of the communes of the county. 


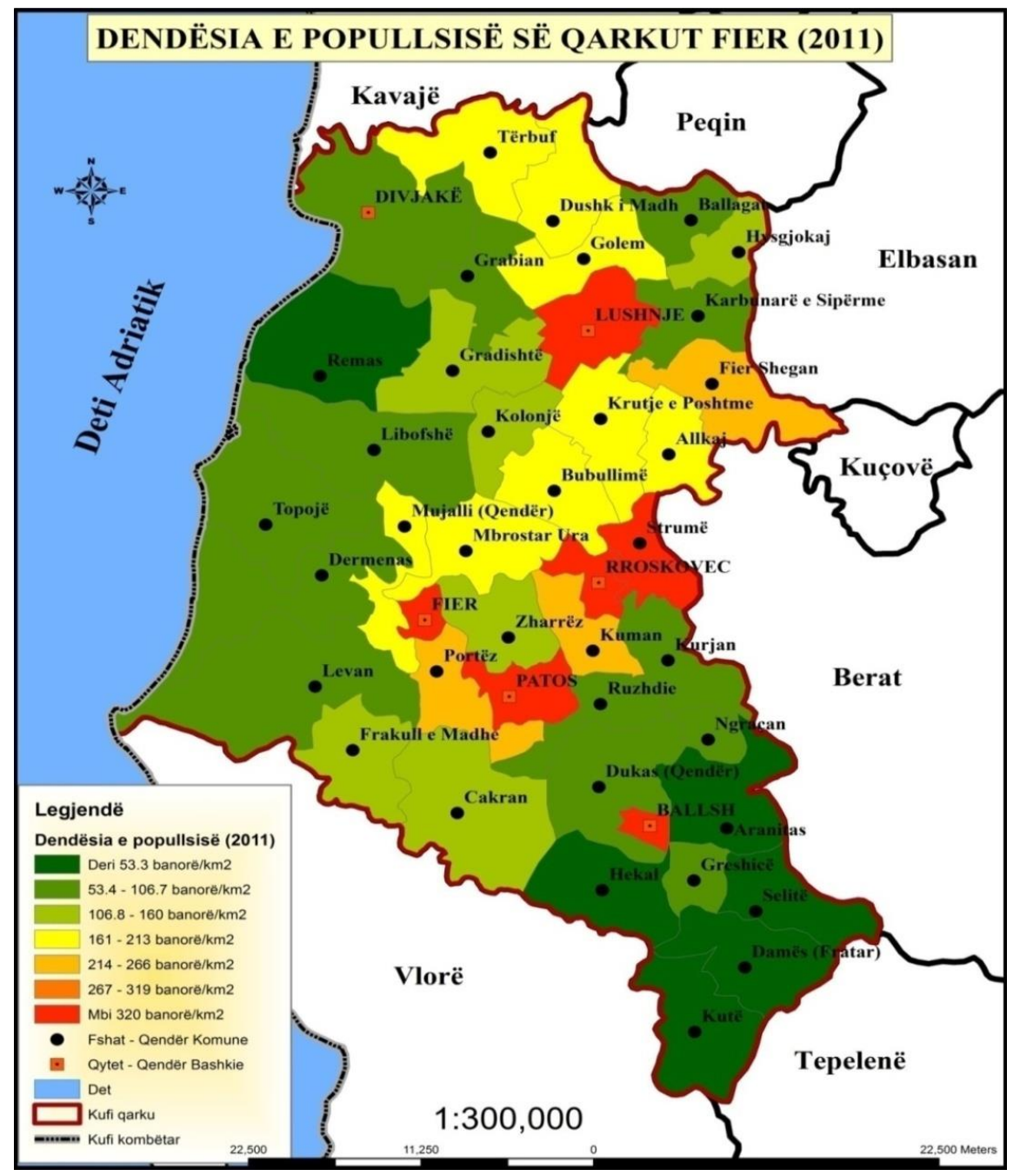

Figure No. 5. The map of population density in Fieri region. [4].

Accrued by A.Dhromaj

The inequalities seen in the distribution of the population of the county call for a stronger local and regional commitment so as not to widen the disequilibrium between population and development. Because the human resources (consummer-producer) in the process of development, constitute the key components of progress and development.

\section{REFERENCES}

[1] INSTAT Popullsia e Shqipërisë në vitin 2001 REPOBA Qarku Fier, Tiranë 2001

[2] INSTAT Republic of Albania Directorate of Statistics Fier, Lushnje, Mallakastër. Yearbook of statistics for the districts Fier, Lushnje, Mallakastër.

[3] INSTAT Republic of Albania Directorate of Statistics Fier, Lushnje, Mallakastër.

Yearbook of statistics for the districts Fier, Lushnje, Mallakastër 2002- 2007-20102011.

[4] INSTAT Republika e Shqipërisë. Censusi i Popullsisë dhe Banesave, FIER 2011

[5] Vjetari statistikor i RPS të Shqipërisë 1989, Tiranë, 1990 
